\title{
An RNA polymerase preparation from Methylobacterium extorquens AM1 capable of transcribing from a methylotrophic promoter
}

\author{
Juan Davagnino, ${ }^{1} \dagger$ Amy L. Springer ${ }^{1}$ and Mary E. Lidstrom ${ }^{1,2}$ \\ Author for correspondence: Mary E. Lidstrom. Tel: +1 206616 5282. Fax: +1 2066165721. \\ e-mail: lidstrom@u.washington.edu
}

Department of Chemical Engineering ${ }^{1}$, Box 351750 and Department of Microbiology2, Box 357242, University of Washington, Seattle, WA 98195-1750, USA

Keywords: RNA polymerase, Methylobacterium extorquens AM1, sigma factor

\section{INTRODUCTION}

Methylobacterium extorquens AM1 is a pink-pigmented facultative methylotroph that can grow on methanol as its sole source of carbon and energy (Lidstrom, 1991). The genetics of methanol oxidation have been studied extensively in this organism (Laufer \& Lidstrom, 1992; Morris et al., 1994; Springer et al., 1995) and in the related methanol oxidizer Metbylobacterium organophilum XX (Bastien et al., 1989; Machlin et al., 1987; Xu et al., 1993, 1995). At least 26 genes are required for the production of active methanol dehydrogenase (MDH) in $M$. extorquens AM1, including genes encoding the structural polypeptides and the cytochrome $c_{\mathrm{L}}$ electron acceptor, genes required for insertion of calcium into the protein, genes required for synthesis of the pyrroloquinoline quinone prosthetic group, genes required for transcription of other methanol oxidation genes, and genes required for unknown assembly functions (Day et al., 1990; Lee et al., 1991; Lidstrom et al., 1994; Morris

†Present Address: Baxter Healthcare, Co., 1720 Flower Avenue, Duarte, CA 91010, USA.

Abbreviations: $\mathrm{MDH}$, methanol dehydrogenase; RNAP, RNA polymerase. et al., 1994; Nunn \& Lidstrom, 1986a, b). The gene encoding the large subunit of $\mathrm{MDH}, m x a F$, has been cloned and sequenced and the transcriptional start site has been mapped to a guanine residue 167 bases upstream of the translational start site (Anderson \& Lidstrom, 1988; Anderson et al., 1990). MDH activity and $\mathrm{MDH}$ polypeptides are present at higher levels in cells grown on $\mathrm{C}_{1}$ compounds than on succinate, and studies with mxaF-lacZ fusions have shown that the induction of $m x a F$ in response to $\mathrm{C}_{1}$ compounds occurs at the transcriptional level (Morris \& Lidstrom, 1992). At least five regulatory genes are required for $m x a F$ transcription, and these apparently comprise three sensor-kinase/response-regulator systems (Morris \& Lidstrom, 1992; Xu et al., 1993; Springer et al., 1997). It is not yet known how these regulatory systems interact, which of the putative response regulators bind at the $m x a F$ promoter, or whether other transcriptional factors such as specific $\sigma$ factors are required.

To further our understanding of transcriptional regulation in methylotrophs, an in vitro transcription system is necessary. This study describes the purification and characterization of RNA polymerase from $M$. extorquens AM1, and shows that the purified holoenzyme 
is capable of initiating specifically at a methylotrophic promoter in vitro.

\section{METHODS}

Media and growth conditions. Rifamycin-resistant $M$. extorquens AM1 (Nunn \& Lidstrom, 1986a) was grown to lateexponential phase in minimal medium (Fulton et al., 1984) containing $0.2 \%(\mathrm{v} / \mathrm{v})$ methanol or $0.2 \%(\mathrm{w} / \mathrm{v})$ succinate. The cells were harvested by centrifugation at $11000 \mathrm{~g}$ for $20 \mathrm{~min}$ at $4{ }^{\circ} \mathrm{C}$. The pellet was frozen at $-20^{\circ} \mathrm{C}$. Chemicals were obtained from Sigma.

Cell extracts. Pellets resulting from 2 litres of cell culture (approximately $2 \mathrm{~g}$ wet weight) were resuspended in $12 \mathrm{ml}$ buffer solution A (Westpheling et al., 1985): $20 \mathrm{mM}$ Tris $/ \mathrm{HCl}$ (pH 8), $5 \mathrm{mM} \beta$-mercaptoethanol, $20 \mathrm{mM} \mathrm{MgCl}_{2}, 1 \mathrm{mM}$ EDTA, $50 \mathrm{mM} \mathrm{NaCl}, 10 \%$ (v/v) glycerol and $1 \mathrm{mM}$ phenylmethylsulfonyl fluoride. The cells were passed through a French press three times at a pressure of 20000 p.s.i. $(138 \mathrm{MPa})$. These samples were then centrifuged at $40000 \mathrm{~g}$ for $1 \mathrm{~h}$ and the supernatant was used as a crude cell extract.

Assay for RNA polymerase (RNAP) activity. The reaction cocktail contained $(1 \times): 40 \mathrm{mM}$ Tris $/ \mathrm{HCl}(\mathrm{pH} 8), 10 \mathrm{mM}$ $\mathrm{MgC}_{1}, 1 \mathrm{mM}$ DTT, $1 \mathrm{mM}$ spermidine, $0.8 \mathrm{mM} \mathrm{ATP}, 0.8 \mathrm{mM}$ CTP, $0.8 \mathrm{mM}$ GTP, $0.08 \mathrm{mM}$ UTP, $5 \mu \mathrm{g}\left[{ }^{3} \mathrm{H}\right] \mathrm{UTP}(0.14 \mu \mathrm{Ci}$, $5.18 \mathrm{kBq}$; New England Nuclear). Fractions from the different purification steps were mixed $1: 1$ with $2 \times$ reaction cocktail and incubated at $20-22^{\circ} \mathrm{C}$ for $1 \mathrm{~h}$. The liquid was then transferred to DE81 paper disks. After the liquid had been adsorbed, the filters were dropped in a $4 \%(\mathrm{w} / \mathrm{v})$ solution of $\mathrm{Na}_{2} \mathrm{HPO}_{4}$. After $3 \mathrm{~min}$ the disks were transferred to a fresh $4 \% \mathrm{Na}_{2} \mathrm{HPO}_{4}$ solution and after another $3 \mathrm{~min}$ they were rinsed twice in water and twice in $95 \%(\mathrm{v} / \mathrm{v})$ ethanol, dried at room temperature and their radioactivity was measured in scintillation fluid. Purified E. coli RNAP $\left(\mathrm{E} \sigma^{70}\right)$, used as a control for activity, was obtained from Sigma.

Enzyme purification. Chromatographic resins were obtained from Sigma. All purification steps were carried out at $4{ }^{\circ} \mathrm{C}$.

Gel filtration chromatography. A $13 \mathrm{ml}$ sample of the crude cell extract was applied to a Sephacryl S200 column ( $f=5.31 \mathrm{~cm}^{2}$, $h=95 \mathrm{~cm}$, vol. $=504 \mathrm{ml}$ ) previously equilibrated in $10 \mathrm{mM}$ Tris/ $\mathrm{HCl}$ ( $\mathrm{pH} \mathrm{8}$ ), $10 \mathrm{mM} \beta$-mercaptoethanol, $10 \mathrm{mM} \mathrm{MgCl}$, $1.5 \mathrm{M} \mathrm{NaCl}, 10 \%$ (v/v) glycerol and $1 \mathrm{mM}$ phenylmethylsulfonyl fluoride. The flow rate was $5.4 \mathrm{ml} \mathrm{h}^{-1}$ and $2.7 \mathrm{ml}$ fractions were collected. The activity eluted between fractions 74 and 87.

Heparin-agarose. The Sephacryl pool was diluted 11-fold with $10 \mathrm{mM}$ Tris/ $\mathrm{HCl}$ (pH 8), $1 \mathrm{mM}$ EDTA, 0.3 mM DTT, $10 \mathrm{mM}$ $\mathrm{MgCl}_{2}, 7 \cdot 5 \%$ (v/v) glycerol and $1 \mathrm{mM}$ phenylmethylsulfonyl fluoride. The diluted pool was applied to a $20 \mathrm{ml}$ heparinagarose column and the RNAP activity was eluted with a $0.1-0.8 \mathrm{M} \mathrm{KCl}$ gradient in dilution buffer. Total gradient volume was $300 \mathrm{ml} ; 4 \mathrm{ml}$ fractions were collected. The activity eluted in fractions containing between 0.35 and $0.55 \mathrm{M} \mathrm{KCl}$.

DEAE Trisacryl Plus $M$. The heparin pool was diluted fourfold with $10 \mathrm{mM}$ Tris/ $\mathrm{HCl}$ (pH 8), $1 \mathrm{mM}$ EDTA, $5 \mathrm{mM} \beta$ mercaptoethanol, $10 \mathrm{mM} \mathrm{MgCl}_{2}, 10 \%$ (v/v) glycerol and $1 \mathrm{mM}$ phenylmethylsulfonyl fluoride. The diluted pool was applied to a DEAE Trisacryl Plus M column, the column was washed to remove unbound proteins using dilution buffer plus $0.05 \mathrm{M} \mathrm{NaCl}$ and the activity was eluted with dilution buffer containing a $0.05-1 \mathrm{M} \mathrm{NaCl}$ gradient. Total gradient volume was $60 \mathrm{ml}$. The pool was precipitated with ammonium sulfate solution at $65 \%$ of saturation and the pellet was dissolved in storage buffer (Westpheling et al., 1985) : $50 \mathrm{mM}$ Tris $/ \mathrm{HCl}$ (pH 8), $1 \mathrm{mM}$ EDTA, $1 \mathrm{mM}$ DTT, 50\% (v/v) glycerol and $50 \mathrm{mM} \mathrm{KCl}$. The purified enzyme preparation was stored at $-20^{\circ} \mathrm{C}$.

Immunoblots. Polyacrylamide gels $(8.7 \%, \mathrm{w} / \mathrm{v}$, acrylamide) were prepared according to the method of Laemmli (1970). The proteins were transferred to PVDF membranes by electrophoresis at $100 \mathrm{~V}$ for $10-12 \mathrm{~h}$. The membranes were blocked with $20 \mathrm{mM}$ Tris, $0.5 \mathrm{M} \mathrm{NaCl}, 0.2 \%$ (w/v) Tween 80 (TBS), and $10 \%(\mathrm{w} / \mathrm{v})$ dried milk for $1 \mathrm{~h}$, and the E. coli anti$\sigma^{70}$ antibody was added at a final dilution of 1/500 in TBS and incubated for $2 \mathrm{~h}$. The membranes were washed three times in TBS, and the anti-rabbit IgG-peroxidase conjugate was added at a final dilution of $1 / 5000$. After $2 \mathrm{~h}$ incubation, the membrane was washed three times in TBS and the peroxidase activity was developed with the ECL (enhanced chemiluminescence) kit from Amersham Life Science.

Isolation of proteins for $\mathbf{N}$-terminal sequence analysis. Isolation and N-terminal sequence analysis of RNAP subunits were carried out as described by Semrau et al. (1995).

PCR amplification of promoter fragments. DNA used in transcription runoff experiments was made by PCR amplification of DNA fragments from the $M$. extorquens AM1 clone 410XSpro7 (Morris \& Lidstrom, 1992; GenBank accession number M31108). For fragment UD392, the primers were KP-U2 (5'-CCGCCCCCGGCCCAAACCAC-3') and KP-D1 (5'-CCTCGCGGTATCTCTCAGACG-3'). For fragment UD352, the primers were KP-U2 and AS-D3 (5'CGCATCGTGAATCTAAGG-3'), and for fragment NEG643 the primers were KP-U1n (5'-CATCGGGCACCGGCTGGC$\left.3^{\prime}\right)$ and AS-N2 (5'-CCAAGGCGTAGTGTCGCAAC-3'). Reactions were carried out using reagents and protocols from the PCR core kit (Boehringer Mannheim), except that the KPU2/KP-D1 and KP-U2/AS-D3 reaction mixtures contained $2 \%(\mathrm{v} / \mathrm{v}) \mathrm{DMSO}$, and the KP-U1n/AS-N2 reaction contained $5 \%$ DMSO and $0.5 \mathrm{mM} \mathrm{MgCl}_{2}$. Amplification products were separated on $0.8 \%(\mathrm{w} / \mathrm{v}$ ) TAE-agarose gels (Sambrook et al., 1989) and were purified from the gels using Geneclean (Bio101).

Protein purification for runoff assays. Approximately $10 \mathrm{~g}$ (wet weight) of cells were suspended in buffer solution $A$ as above, and passed through a French press twice at a pressure of 20000 p.s.i. (138 MPa). These samples were then centrifuged at $40000 \mathrm{~g}$ for $90 \mathrm{~min}$ and the supernatant was applied to a $10 \mathrm{ml}$ heparin agarose column. The column was washed with buffer $A$ to remove unbound proteins and the activity was eluted in a step process using buffer A containing $0.25 \mathrm{M}$ $\mathrm{KCl}(50 \mathrm{ml}), 0.50 \mathrm{M} \mathrm{KCl}(50 \mathrm{ml})$, and then $0.75 \mathrm{M} \mathrm{KCl}(50 \mathrm{ml})$. The middle fraction was collected and precipitated with an ammonium sulfate solution at $65 \%$ saturation. The pellet was dissolved in storage buffer. The enzyme was stored at $-20^{\circ} \mathrm{C}$.

Transcription run-off assay. One microlitre of the crude enzyme preparation was used in $40 \mu$ l reactions containing $1-2 \mu \mathrm{g}$ DNA, $1 \mu \mathrm{l}(5 \mathrm{U}) \mathrm{RNase}$ inhibitor and $25 \mu \mathrm{l}$ reaction buffer $\left[1.2 \mathrm{mg} \mathrm{ml}^{-1}\right.$ bovine serum albumin (BSA), $800 \mu \mathrm{M}$ DTT, $800 \mu \mathrm{M}$ EDTA, $32 \%(\mathrm{v} / \mathrm{v})$ glycerol and $11.5 \mu \mathrm{l} 2 \times$ Master mix (per $70 \mathrm{ml}: 1.21 \mathrm{~g}$ Tris base, $9.3 \mathrm{mg} \mathrm{Na} \mathrm{ND}_{2}$ TA, $125 \mathrm{mg} \mathrm{BSA}, 487 \cdot 2 \mathrm{mg} \mathrm{MgCl}_{2} \cdot 6 \mathrm{H}_{2} \mathrm{O}, 25 \mathrm{ml} 4 \mathrm{mM} \mathrm{KPO}$, $\mathrm{pH} 7.5$; mixture adjusted to $\mathrm{pH} 7 \cdot 9$ )]. Reactions were carried out as described by Westpheling et al. (1985). Pellets were resuspended in $10 \mu \mathrm{l}$ TBE-urea sample buffer (Novex) and stored at $-20^{\circ} \mathrm{C}$. Samples $(2 \mu \mathrm{l})$ from these reaction mixtures were loaded into $6 \%(\mathrm{w} / \mathrm{v})$ TBE-urea acrylamide gels 
(Novex). Purified E. coli $\mathrm{E} \sigma^{70}$ was used as a control for activity. Size markers were pBR322 (Gibco-BRL) digested with Hinfl or MspI.

\section{RESULTS}

\section{Purification of RNA polymerase from $M$. extorquens AM1}

Purification of RNAP from crude cell extract is described in Methods. The results from each step in the purification are shown in Fig. 1. The final enzyme preparation contained six polypeptide bands of approximately $200+$ (doublet), 97, 43, 40 and $24 \mathrm{kDa}$, as visualized on SDSPAGE (Figs 1 and 2). Four of these were the correct size to be the $\beta^{\prime}, \beta, \alpha$ and $\omega$ subunits as compared to E. coli RNAP (Figs 1 and 2). No polypeptide co-migrated with the $E$. coli $\sigma^{70}$ subunit. Two polypeptides in the $M$. extorquens AM1 preparation, running at $40 \mathrm{kDa}$ and $97 \mathrm{kDa}$ (designated p40 and p97, respectively), did not correspond to polypeptides found in E. coli RNAP. The same pattern of RNAP subunits was found for enzyme purified from $M$. extorquens AM1 grown on succinate or grown on methanol.

\section{$\mathbf{N}$-terminal sequence analysis of subunit proteins}

$\mathrm{N}$-terminal amino acid sequences were obtained for three of the polypeptides: the putative $\omega$ subunit, p97 and $\mathrm{p} 40$. The $\mathrm{N}$-terminal sequence of the putative $\omega$

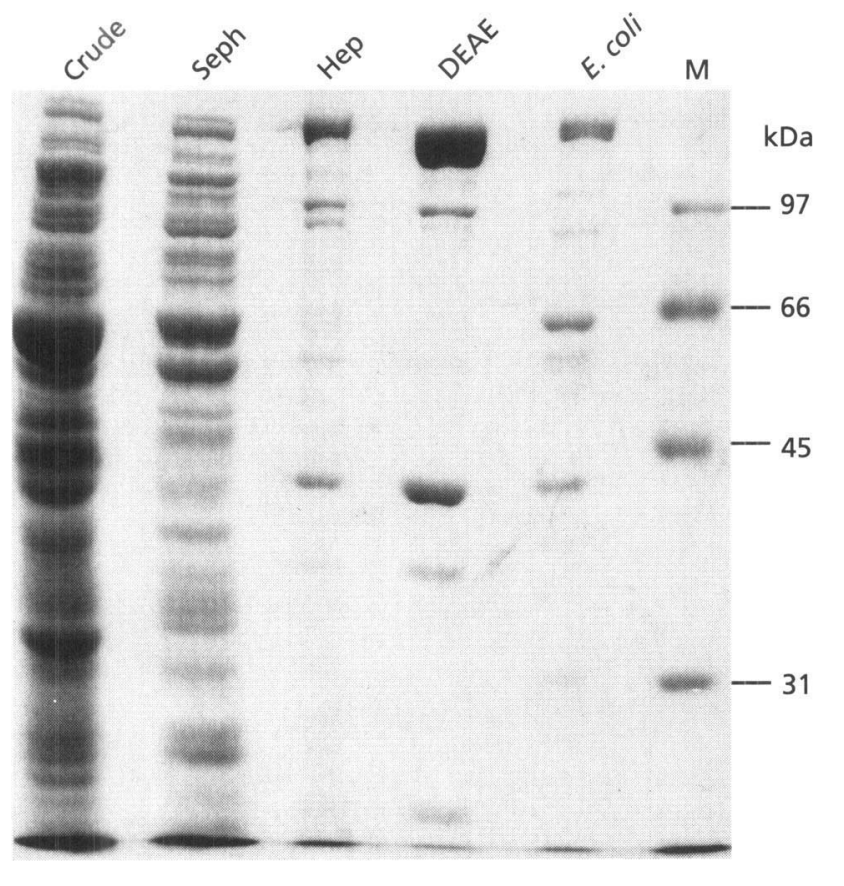

Fig. 1. SDS-PAGE of fractions from the purification of RNAP from $M$. extorquens AM1. Each lane shows successive steps in the purification of active RNAP; steps are described in Methods. Crude, crude extract; Seph, Sephacryl pool; Hep, heparin agarose pool; DEAE, DEAE Trisacryl Plus M pool. E. coli, E. coli RNAP; $M$, molecular mass markers (Bio-Rad, low range). Protein loaded $(\mu \mathrm{g})$ : Crude, 110; Seph, 45; Hep, 17; DEAE, 27; E. coli, 12. (a)



Fig. 2. Detection of polypeptides cross-reacting with antibody to $E$. coli $\sigma^{70}$. (a) Coomassie-stained SDS-PAGE gel; (b) immunoblot with anti-E. coli $\sigma^{70}$ antibody. Lanes show $E$. coli and $M$. extorquens AM1 RNAPs (labelled $E$. $C$. and AM1, respectively). RNAP subunits, including p97 and p40 from $M$. extorquens AM1 RNAP preparation, are indicated between the panels. M, molecular mass markers (Bio-Rad, low range).

polypeptide showed a high degree of identity to E. coli $\omega$ subunit and to $\omega$ subunits of other bacteria (see Table 1 for examples). The $\mathrm{N}$-terminal sequence of $\mathrm{p} 97$ shared a high degree of identity with primary $\sigma$ factors of many bacteria. The two polypeptides showing the highest amino acid identity to the $\mathrm{p} 97$ sequence were SigA from Agrobacterium tumefaciens (61\% over 33 amino acids) and SigA from Rhizobium (Sinorhizobium) meliloti $(58 \%$ over 33 amino acids; Table 1$)$. However, no significant identity was found between p97 and E. coli $\sigma^{70}$. The $\mathrm{N}$-terminal sequence of $\mathrm{p} 40$ showed that this polypeptide shares identity with another class of $\sigma$ factors, the $\sigma^{32}$ homologues. The polypeptides showing the highest identity were RpoH of A. tumefaciens $(67 \%$ over 35 amino acids) and $\mathrm{RpoH}$ of Caulobacter crescentus (63\% over 36 amino acids; Table 1$)$. A lesser degree of identity was found between $\mathrm{p} 40$ and some group 2 alternative $\sigma$ factors (Table 1), such as $\mathrm{HrdB}$ of Streptomyces coelicolor ( $37 \%$ over 30 amino acids). 
Table 1. $\mathrm{N}$-terminal sequences of selected proteins from RNA polymerase of $M$. extorquens AM1

\begin{tabular}{|c|c|c|c|}
\hline $\begin{array}{l}\text { AM1 } \\
\text { protein }\end{array}$ & $\mathrm{N}$-terminal sequence & Identity* & Homologue \\
\hline p97 & ATKATERDDADAAQDQPTDGPLLDLTDAAVK & $\begin{array}{l}61 \% \text { SigA of } A . \text { tumefaciens }^{a} \\
58 \% \text { SigA of } R . \text { meliloti }^{b}\end{array}$ & $\begin{array}{l}\sigma^{70} \\
\sigma^{70}\end{array}$ \\
\hline $\mathrm{p} 40$ & AGALPVLANEGGLSRYLDEIRKFPMLEPAEEFTLAK & $\begin{array}{l}67 \% \mathrm{RpoH} \text { of } A . \text { tumefaciens }^{c} \\
63 \% \mathrm{RpoH} \text { of C. } \text { crescentus }^{d} \\
37 \% \mathrm{HrdB} \text { of } S . \text { coelicolor }^{e}\end{array}$ & $\begin{array}{c}\sigma^{32} \\
\sigma^{\mathrm{s}}\end{array}$ \\
\hline$\omega$ & ARVTVEDSIEKVENRFELVLLAAHRARLLAAG & $\begin{array}{l}66 \% \mathrm{RpoZ} \text { of } H . \text { influenzae } \\
63 \% \mathrm{RpoZ} \text { of } E . \text { coli }^{g}\end{array}$ & $\begin{array}{l}\omega \\
\omega\end{array}$ \\
\hline
\end{tabular}

* $a$, Identity is over 33 amino acids, GenBank accession number X69388; $b$, identity is over 33 amino acids, GenBank accession number L47288; $c$, identity is over 35 amino acids, GenBank accession number U37792; $d$, identity is over 36 amino acids, GenBank accession number D50828; $e$, identity is over 30 amino acids, GenBank accession number M90411; $f$, identity is over 29 amino acids, GenBank accession number A29038; $\mathrm{g}$, identity is over 32 amino acids, GenBank accession number G64139.

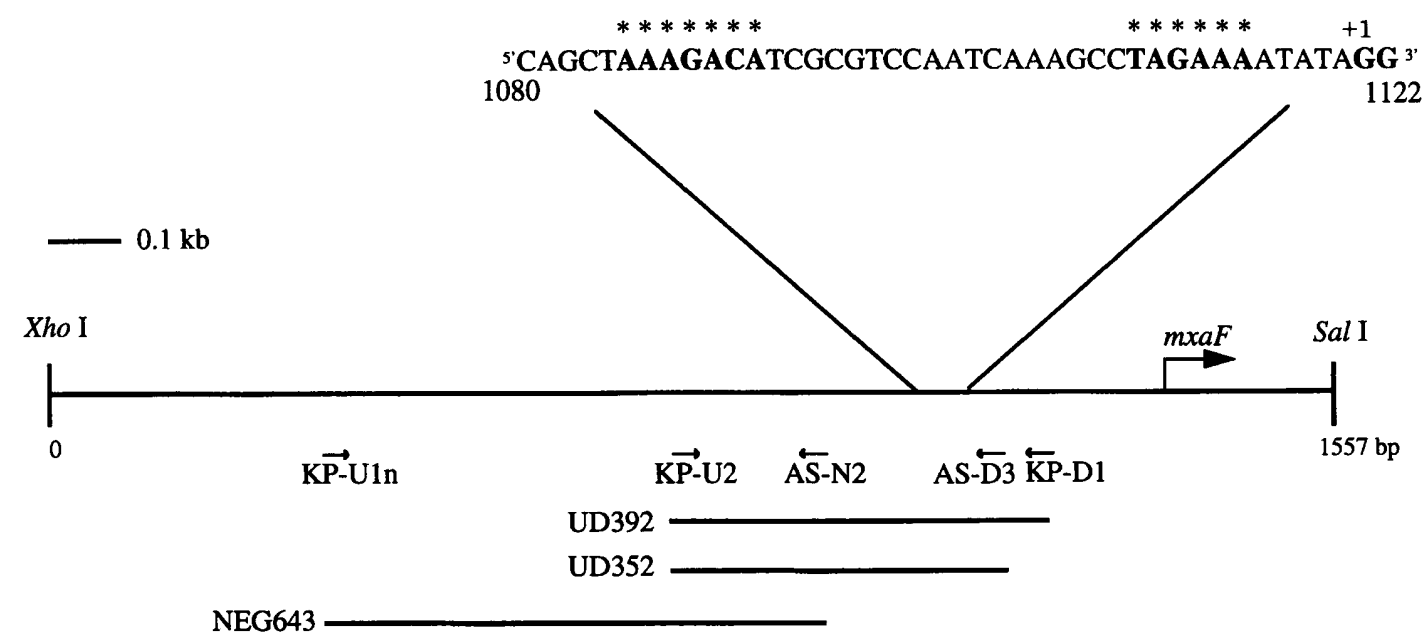

Fig. 3. Diagram showing the promoter region of mxaF used in transcription experiments. The region shown is the $1.56 \mathrm{~kb}$ Xhol-Sall fragment from 410XSpro7 (Morris \& Lidstrom, 1992). The NEG643, UD352 and UD392 PCR products and their respective oligonucleotide primers are shown (for sequences of these primers, see Methods). The sequence of 42 bases around the promoter region is shown (for the entire sequence, refer to GenBank accession number M31108), the transcription start site at positions 1121-1122 is indicated in bold with ' +1 ' above, and putative -35 and -10 regions are indicated in bold with asterisks above. The translational start site of $m \times a F$ is indicated with an arrow.

\section{Immunoblotting with antibody to $E$. coli $\sigma^{70}$}

It was possible that $\sigma^{70}$ homologues were present in the M. extorquens AM1 RNAP that were not detectable in Coomassie-stained gels. To determine if group $1 \sigma^{70}$ homologues similar to SigA of E. coli were present, but had been missed, immunoblot analysis was performed using antibody to $E$. coli $\sigma^{70}$. As shown in Fig. 2, a band is visible in the E. coli RNAP lane but no bands are visible in the $M$. extorquens AM1 RNAP lane. This indicates that the $M$. extorquens AM1 preparation does not contain a polypeptide that cross-reacts with the $\sigma^{70}$ antibody at detectable levels.

\section{Transcription runoff experiments}

To demonstrate that the $M$. extorquens AM1 RNAP preparation was active and could initiate transcription at a methylotrophic promoter, transcription runoff experiments were performed using DNA from a known methylotrophic promoter. Transcription of $m x a F$, encoding the large subunit of $\mathrm{MDH}$, has been well studied (Anderson \& Lidstrom, 1988; Morris \& Lidstrom 1992). This gene has a methanol-inducible promoter, the transcriptional start site is known (Anderson et al., 1990 ), and putative -35 and -10 promoter sequences have been identified (Lidstrom \& Stirling, 1990). There- 


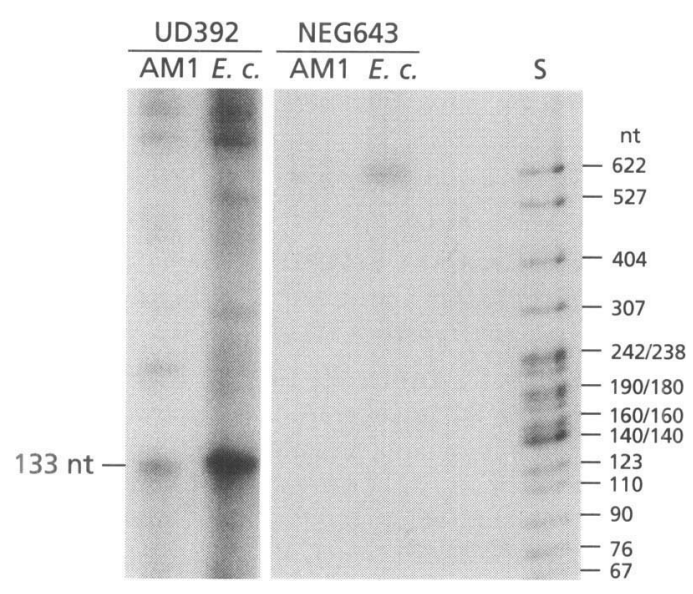

Fig. 4. Transcription run-off experiment showing initiation at the mxaF start site. PCR products UD392 and NEG643 were incubated with $M$. extorquens AM1 or $E$. coli $(E$. C.) RNAP preparations, as indicated. The expected transcription product of UD392 is $133 \mathrm{nt}$ and is indicated on the left of the figure. S, size markers (pBR322 digested with Mspl).

fore, this region was chosen to generate templates for run-off transcription assays. Fragment UD392 contains the putative promoter region and the transcription start site and should generate a transcript of 133 nt (Fig. 3). Fragment NEG643 contains part of the putative promoter region but does not include the transcriptional start site, and was used as a negative control. Fig. 4 shows the results of runoff experiments with UD392 and NEG643. A transcript of the expected size (133 nt) was found with UD392 and no transcript was obtained with the NEG643 control. To confirm this result, a separate experiment was carried out with a second fragment (UD352) that also contained the putative promoter and transcriptional start site, but had a $3^{\prime}$ end closer to the transcriptional start site (Fig. 3). A transcript of the expected size (93 $\mathrm{nt}$ ) was also observed for this fragment (data not shown). Transcripts were produced from both the purified $M$. extorquens RNAP and the E. coli RNAP, indicating that the $E$. coli enzyme can recognize a promoter sequence in the region of the $m x a F$ promoter. These experiments indicate that the $M$. extorquens AM1 RNAP preparation is capable of initiating transcription specifically at the start site of the mxaF promoter.

\section{DISCUSSION}

RNAP purified from M. extorquens AM1 contained two subunits that appeared to be $\sigma$ factors. The $\mathrm{N}$-terminal amino acid sequence of $\mathrm{p} 97$ shared identity with the primary $\sigma$ factors from Agrobacterium tumefaciens and Rhizobium (Sinorhizobium) meliloti (Table 1). These primary $\sigma$ factors are in the family of group $1 \sigma \mathrm{s}$, closely related to the E. coli $\sigma^{70}$ (Lonetto et al., 1992). However, p97 did not co-migrate with $E$. coli $\sigma^{70}$, did not crossreact with $E$. coli $\sigma^{70}$ antisera, and did not share significant identity in its N-terminal region. None- theless, its identity with the other primary $\sigma$ factors and its predominance in the RNAP preparation suggests that it is likely to be the primary $\sigma$ factor for M. extorquens AM1.

p 40 had a high degree of identity with $\sigma^{32}$ homologues (Table 1), which are part of the cellular stress response in other bacteria (Mager \& De Kruijff, 1995). The high identity between the N-termini of p40 and $\sigma^{32}$ homologues may indicate that $\mathrm{p} 40$ is a methylotrophic stress response $\sigma$ factor. p 40 shared a lesser degree of identity with some group 2 alternative $\sigma$ factors (Table 1$)$. The group $2 \sigma$ factors are generally non-essential and share some identity with the group $1 \sigma$ factors, particularly in their DNA-binding regions (Lonetto et al., 1992). Thus, it is also possible that p 40 is an alternative $\sigma$ factor in $M$. extorquens AM1. p40 appeared to be present at lower levels than $\mathrm{p} 97$ (Fig. 2), suggesting that these purified preparations contained a mixture of the normal vegetative RNAP containing p97 $\sigma$ factor $\left(\mathrm{E} \sigma^{97}\right)$, with a smaller amount of RNAP containing the $440 \sigma$ factor $\left(\mathrm{E} \sigma^{40}\right)$.

A similar pattern of $\sigma$ subunits has been observed for RNAP from Rhodobacter sphaeroides (Karls et al., 1993). In this case, a subunit of $93 \mathrm{kDa}$ appeared to be the $\sigma^{70}$ homologue, while a subunit of $37 \mathrm{kDa}$ appeared to be the $\sigma^{32}$ homologue. It is not clear why these bacteria would contain a significant amount of $\sigma^{32}$. containing RNAP during normal growth. However, in the case of $M$. extorquens AM1, the cells produce formaldehyde as their central metabolic intermediate, which might result in a constant production of misfolded or denatured proteins that could require a continual production of stress-response proteins.

No difference was observed in the pattern of $\sigma$ factors between cells grown on methanol and cells grown on succinate, suggesting that the methanol-mediated induction of mxaF in $M$. extorquens AM1 (Morris \& Lidstrom, 1992) does not involve a major methanolinducible $\sigma$ factor. However, we cannot rule out the presence of a minor population of RNAP enzymes with a methanol-inducible $\sigma$ factor, responsible for transcription of methylotrophic promoters.

The fact that the E. coli $\sigma^{70}$ RNAP preparation initiated transcription at or near the $m x a F$ promoter suggests the presence of a $\sigma^{70}$ like promoter. The sequence in Fig. 3 shows that the proposed -10 and -35 sequences for the mxaF promoter bear some resemblance to the $\sigma^{70}$ consensus sequence. Therefore, it is possible that in both the E. coli and M. extorquens AM1 RNAP preparations, the $m x a F$ promoter was transcribed using $\sigma^{70}$.

The transcription runoff experiments described here demonstrate that the $M$. extorquens AM1 RNAP preparation is capable of recognizing methylotrophic promoters and initiating specifically at the mxaF start site. This result suggests that in vitro studies of transcription in methylotrophs should be possible with these RNAP preparations. Such studies will be used to identify the specific sequences and factors important for transcription at methylotrophic promoters. 


\section{ACKNOWLEDGEMENTS}

This research was supported by a grant from the Department of Energy (DEFG03-96ER20226). We are grateful to C. Gross (UC San Francisco) for supplying the anti- $\sigma^{70}$ antibody.

\section{REFERENCES}

Anderson, D. J. \& Lidstrom, M. E. (1988). The moxFG region encodes four polypeptides in the methanol-oxidizing bacterium Methylobacterium extorquens AM1. J Bacteriol 170, 2254-2262.

Anderson, D. J., Morris, C. J., Nunn, D. N., Anthony, C. \& Lidstrom, M. E. (1990). Nucleotide sequence of the Methylobacterium extorquens sp. AM1 mox $F$ and $J$ genes involved in methanol oxidation. Gene 90, 173-176.

Bastien, C., Machlin, S., Zhang, Y., Donaldson, K. \& Hanson, R. S. (1989). Organization of genes required for the oxidation of methanol to formaldehyde in three type II methylotrophs. Appl Environ Microbiol 55, 3124-3130.

Day, D. J., Nunn, D. N. \& Anthony, C. (1990). Characterization of a novel soluble $c$-type cytochrome in a $\operatorname{moxD}$ mutant of Methylobacterium extorquens AM1. J Gen Microbiol 136, 181-188.

Fulton, G. L., Nunn, D. N. \& Lidstrom, M. E. (1984). Molecular cloning of a malyl CoA lyase gene from Pseudomonas AM1, a facultative methylotroph. J Bacteriol 160, 718-723.

Karls, R. K., Jin, D. J. \& Donohue, T. J. (1993). Transcription properties of RNA polymerase holoenzymes isolated from the purple non-sulfur bacterium Rhodobacter sphaeroides. $J$ Bacteriol 175, 7629-7638.

Laemmli, U. K. (1970). Cleavage of structural proteins during the assembly of the head of bacteriophage T4. Nature 227, 680 .

Laufer, K. \& Lidstrom, M. E. (1992). Regulation and expression of bacterial quinoproteins. In Quinoproteins, pp. 193-222. Edited by V. Davidson. New York: Marcel Dekker.

Lee, K. E., Stone, S., Goodwin, P. M. \& Holloway, B. W. (1991). Characterization of transposon insertion mutants of Methylobacterium extorquens AM1 (Methylobacterium strain AM1) which are defective in methanol oxidation. J Gen Microbiol 137, 895-904.

Lidstrom, M. E. (1991). The aerobic methylotrophic bacteria. In The Prokaryotes II, pp. 431-445. Edited by A. Balows, H. G. Trüper, M. Dworkin, W. Harder and K.-H. Schleifer. New York: Springer.

Lidstrom, M. E. \& Stirling, D. I. (1990). Methylotrophs: genetics and commercial applications. Annu Rev Microbiol 44, 27-58.

Lidstrom, M. E., Anthony, C., Biville, F., Gasser, F., Goodwin, P., Hanson, R. S. \& Harms, N. (1994). New unified nomenclature for genes involved in the oxidation of methanol in Gram-negative bacteria. FEMS Microbiol Lett 117, 103-106.

Lonetto, M., Gribskov, M. \& Gross, C. A. (1992). The $\sigma^{70}$ family: sequence conservation and evolutionary relationships. J Bacteriol 174, 3843-3849.
Machlin, S. M., Tam, P. E., Bastien, C. A. \& Hanson, R. S. (1987), Genetic and physical analyses of Methylobacterium organophilum XX genes encoding methanol oxidation. J Bacteriol 170, 141-148.

Mager, W. H. \& De Kruijff, A. J. J. (1995). Stress-induced transcriptional activation. Microbiol Rev 59, 506-531.

Morris, C. J. \& Lidstrom, M. E. (1992). Cloning of a methanolinducible $\operatorname{moxF}$ promoter and its analysis in moxB mutants of Methylobacterium extorquens AM1.J Bacteriol 174, 4444 4449.

Morris, C. J., Biville, F., Turlin, E., Lee, E., Ellermann, K., Fan, W.-H., Ramamoorthi, R., Springer, A. L. \& Lidstrom, M. E. (1994). Isolation, phenotypic characterization and complementation analysis of mutants of Methylobacterium extorquens AM1 unable to synthesize pyrroloquinoline quinone and sequences of $p q q D$, $p q q G$ and pqqC. J Bacteriol 176, 1746-1755.

Nunn, D. N. \& Lidstrom, M. E. (1986a). Isolation and complementation analysis of 10 methanol oxidation mutant classes and identification of the methanol dehydrogenase structural gene of Methylobacterium sp. strain AM1. J Bacteriol 166, 581-590.

Nunn, D. N. \& Lidstrom, M. E. (1986b). Phenotypic characterization of 10 methanol oxidation mutant classes in Methylobacterium extorquens sp. strain AM1. J Bacteriol 166, 591-597.

Sambrook, J., Fritsch, E. R. \& Maniatis, T. (1989). Molecular Cloning: a Laboratory Manual, 2nd edn. Cold Spring Harbor, New York: Cold Spring Harbor Laboratory.

Semrau, J. D., Chistoserdov, A., Lebron, J., Costello, A., Davagnino, J., Kenna, E., Holmes, A. J., Finch, R., Murrell, J. C. \& Lidstrom, M. E. (1995). Particulate methane monooxygenase genes in methanotrophs. J Bacteriol 177, 3071-3079.

Springer, A. L., Chou, H.-H., Fan, W.-H., Lee, E. \& Lidstrom, M. E. (1995). Methanol oxidation mutants in Methylobacterium extorquens AM1: identification of new genetic complementation groups. Microbiology 141, 2985-2993.

Springer, A. L., Morris, C. J. \& Lidstrom, M. E. (1997). Molecular analysis of $m x b D$ and $m x b M$, a putative sensor-regulator pair required for oxidation of methanol in Methylobacterium extorquens AM1. Microbiology 143, 1737-1744.

Westpheling, J., Ranes, M. \& Losick, R. (1985). RNA polymerase heterogeneity in Streptomyces coelicolor. Nature 313, 22-27.

Xu, H. H., Viebahn, M. \& Hanson, R. S. (1993). Identification of methanol-regulated promoter sequences from the facultative methylotrophic bacterium Methylobacterium organophilum XX. $J$ Gen Microbiol 139, 743-752.

Xu, H. H., Janka, J. J., Viebahn, M. \& Hanson, R. S. (1995). Nucleotide sequence of the $m x c Q$ and $m x c E$ genes, required for methanol dehydrogenase synthesis in Methylobacterium organophilum XX: a two-component regulatory system. Microbiology $141,2543-2551$.

Received 2 June 1997; revised 12 September 1997; accepted 19 September 1997. 